\title{
Morphology of megalopae from Diogenidae family (Decapoda, Anomura) in Veracruz, south-western Gulf of Mexico: Identification keys to genera and species
}

\author{
Sergio Cházaro-Olvera ${ }^{1,}$, , Ignacio Winfield Aguilar ${ }^{1}$, Manuel Ortiz Touzet ${ }^{1}$, \\ Eduardo Cházaro-Martínez ${ }^{1}$, Horacio Vázquez-López ${ }^{1}$, Guillermo Javier Horta-Puga ${ }^{2}$ \\ ${ }^{1}$ Laboratorio de Crustáceos, Facultad de Estudios Superiores Iztacala, Universidad Nacional Autónoma de México. Av. de los Barrios \\ Numero 1, Los Reyes Iztacala, 54090 Tlalnepantla, Estado de México, México \\ ${ }^{2}$ UBIPRO, Facultad de Estudios Superiores Iztacala, Universidad Nacional Autónoma de México. Av. de los Barrios Numero 1, Los Reyes \\ Iztacala, 54090 Tlalnepantla, Estado de México, México
}

\section{Email address:}

chazaro@campus.iztacala.unam.mx (S. Cházaro-Olvera), ignacioc@unam.mx (I. W. Aguilar), ortiztouzet@yahoo.com (M. O.Touzet), santicoki@gmail.com (E. Cházaro-Martínez), hvazquez@campus.iztacala.unam.mx (H. Vázquez-López),

horta@unam.mx (G. J. Horta-Puga)

\section{To cite this article:}

Sergio Cházaro-Olvera, Ignacio Winfield Aguilar, Manuel Ortiz Touzet, Eduardo Cházaro-Martínez, Horacio Vázquez-López, Guillermo Javier Horta-Puga. Morphology of Megalopae from Diogenidae Family (Decapoda, Anomura) in Veracruz, South-Western Gulf of Mexico: Identification Keys to Genus and Species. American Journal of Life Sciences. Vol. 1, No. 6, 2013, pp. 261-266.

doi: 10.11648/j.ajls.20130106.14

\begin{abstract}
The morphology of Diogenidae megalopa collected in the southwestern Gulf of Mexico was analyzed; the characters considered were: number of segments from the flagellum of the antenna, size and shape of the carapace, number of setae of the scaphognathite of the maxilla, abdomen size, size and number of setae of the endopod and exopod of uropods and number of setae in the posterior margin of telson. A total of 4023 megalopae were obtained and eight species were identified: Calcinus tibicen, Clibanarius antillensis, C. vittatus, C. cubensis, Dardanus insignis, Paguristes sericeus, P. spinipes and Petrochirus diogenes. The species of genus Clibanarius are distinguished by the suboval shape of the telson and have less than nine setae in their posterior margin. The difference between Clibanarius species is given by the number of setae on the scaphognathite of the maxilla and the number of segments in the flagellum of the antenna. The scaphognathite of $D$. insignis and $P$. diogenes have more than 70 setae; the difference between these two species is the number of setae on exopods of the uropods. The megalopa of $P$. sericeus presented six segments on the antenna, $P$. spinipes and $C$. tibicen have 10 segments, the difference between these two species is that $P$. spinipes has 26 setae in the scaphognathite and $C$. tibicen has 65 . With a morphological analysis it was possible to structure a key for genus and species identification. These keys are the first contribution for the identification of Diogenidae megalopae in the southwestern Gulf of Mexico.
\end{abstract}

Keywords: Crustacea, Diogenidae, Paguroids, Megalopa, Southwestern Gulf of Mexico

\section{Introduction}

Paguroids hermit crabs of the families Coenobitidae Dana 1851, Diogenidae Ortmann, 1892, Paguridae Latreille 1802, Parapaguridae Smith, 1882, Pylojacquesidae McLaughlin and Lemaitre, 2001 and Pylochelidae Bate, 1888 include 120 genera [1,2] and, according to the classification of Reference [2], 1106 species.

Particularly, the Diogenidae family is represented by 20 genera and 428 species [2]. In the state of Veracruz, Mexico, 18 species of this family have been found, which is equivalent to $44 \%$ of the crustaceans of the infraorder Anomura [3, 4]; the richness of this species is reflected in the representativeness of larvae and post larvae in the samplings.

It is noteworthy that the presence of paguroids depends on the larval development of the species and, generally, they have one to four zoeal stages before molt to the megalopal stage [2]. The megalopa is able to recognize and use empty snail shells in the marine environment and some species can delay metamorphosis in the absence of shells [5]. This may determine the dynamics of the density and its 
representativeness in the samplings at this stage of development. Sometimes it is difficult to identify the megalopae collected in natural environment, either by the lack of adequate descriptions or their scarce presence in the samples. However, following the development in the laboratory, some keys been developed for the identification of zoea and megalopae of decapod crustaceans, such as the ones described by Reference [6, 7, 8, 9, 10, 11, 12, 13, 14]. In the southwestern Gulf of Mexico the only work known of megalopae Panopeidae family is the one of Reference [15]. That is the reason why the present study aims to analyze the megalopae's morphology of the hermit crabs species of the Dignonidae family collected in the reef Isla Sacrificios in the Veracruz Coral Reef System National Park, Gulf of Mexico and, with this information, to develop identification keys for that post-larval stage.

\section{Material and Methods}

\subsection{Study Area}

The Veracruz Coral Reef System National Park (PNSAV) is located on the continental shelf of the state of Veracruz, Mexico, between $19^{\circ} 00^{\prime} 00^{\prime \prime}-19^{\circ} 16^{\prime} 00^{\prime \prime} \mathrm{N}$, $95^{\circ} 45^{\prime} 00^{\prime \prime}-96^{\circ} 12^{\prime} 00^{\prime \prime} \mathrm{W}$ in the western region of the Gulf of Mexico (Fig. 1). This park includes 23 reefs in an area of 52000 ha, divided into two groups and separated by a soft bottom area set up by the mouth of the Jamapa river: the northern group, opposite the port of Veracruz, represents almost a third part of the park with 12 reefs where Isla Sacrificios is located and the southern group facing Anton Lizardo, has the largest extension with 11 reefs [16].

Reference [17] characterized the PNSAV by the high evaporation, salinities greater than 32 ups, and temperatures above $25^{\circ} \mathrm{C}$; furthermore, they established a net flow of surface circulation towards the north-northwest with the presence of an anticyclonic and a cyclonic twist opposite to the mouth of the Jamapa river.

Biological sampling was carried out on the reef Isla Sacrificios, located in the northern group of PNSAV. The collection was performed using a light trap during the months of July, August and September, 2003.

The megalopae of the hermit crabs of the Diogenidae family were identified in the Laboratory of Crustaceans (FES Iztacala-UNAM) in accordance with the original descriptions of Reference [18, 19, 20, 21, 22, 23] and Reference [24]. The selected taxonomic arrangement was proposed by Reference [2]. The taxonomic identification keys were elaborated with this information.

The diagrams were made using a Leica DM750 microscope equipped with a digital camera Moticam 1 SP of 1.3 MP and the program Corel Draw X6 version 16.0.0 707.

The keys were developed considering the size and shape of the carapace, the number of segments of the antenna, the number antennule segments, the size of the abdomen, the size and number of setae of the endopodite and exopodite of uropods and the number of setae at the posterior margin of telson. The features listed help to identify externally the megalopae of the eight species of the Diogenidae family, and to complete this identification it will only be necessary to carry out micro dissections, watching other features as the number of segments of the antenna, the number of setae of the coxal endite of the maxillule, the number of setae of the scaphognathite, coxal and basal endite of the maxilla and the number of setae of the basipodite of the first maxilliped. Although it was not collected in this study, the species Clibanarius tricolor (Gibbes, 1850) is included in the identification key, considering the number of segments of the antenna reported by Reference [19].

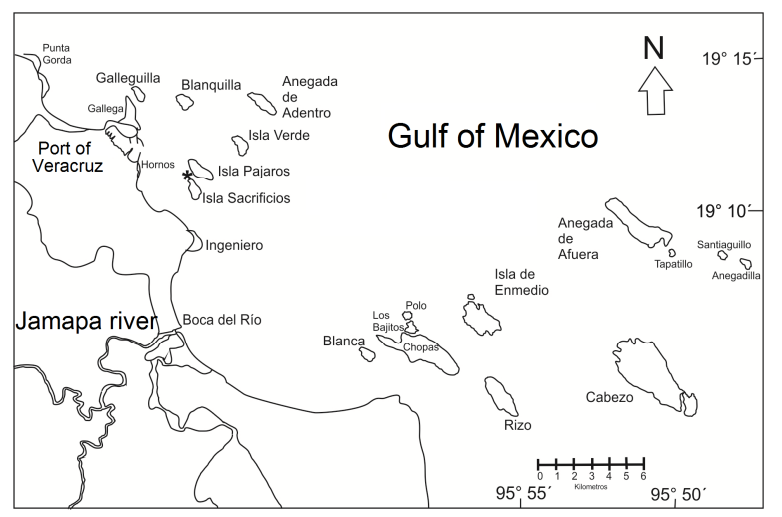

Figure 1. Location of the sampling area (*).

\section{Results}

We found five genera and eight species of megalopae in the Diogenidae family: Calcinus tibicen (Herbst, 1791), Clibanarius antillensis Stimpson, 1859, C. vittatus (Bosc, 1802), C. cubensis (Saussure, 1858), Dardanus insignis (de Saussure, 1858), Paguristes sericeus A. Milne Edwards, 1880, P. spinipes A. Milne-Edwards, 1880, and Petrochirus diogenes (Linnaeus, 1758). A total of 4023 megalopae were collected, and the most abundant species was $C$. vittatus with 1171 megalopae, followed by $C$. antillensis with 968 and $C$. cubensis with 656 . On the other hand, the greatest abundance of megalopae was found between 21:00 and 23:00 hours (Table 1).

Table 1. Abundance of the Diogenidae megalopae in the site of sampling.

\begin{tabular}{lllllll}
\hline Species & & \multicolumn{5}{c}{ Hour of sampling } \\
\hline & $21: 00$ & $22: 00$ & $23: 00$ & $00: 00$ & $01: 00$ & Total \\
Clibanarius antillensis & 216 & 443 & 291 & 13 & 5 & 968 \\
Clibanarius cubensis & 327 & 211 & 86 & 25 & 7 & 656 \\
Calcinus tibicen & 104 & 69 & 44 & 14 & 6 & 237 \\
Clibanarius vittatus & 542 & 364 & 242 & 16 & 7 & 1171 \\
Dardanus insignis & 93 & 61 & 39 & 11 & 1 & 205 \\
Paguristes sericeus & 95 & 89 & 56 & 10 & 3 & 253 \\
Paguristes spinipes & 155 & 74 & 98 & 15 & 4 & 346 \\
Petrochirus diogenes & 78 & 52 & 43 & 12 & 2 & 187 \\
Total & 1610 & 1363 & 899 & 116 & 35 & 4023 \\
\hline
\end{tabular}


The morphological analysis of the species of genus Clibanarius found that both $C$. antillensis as $C$. cubensis present 10 segments on the antenna, while $C$. vittatus presented 11 segments. The three species have from 15 to 16 setae in the coxal endite of the maxillule. Slight variations were observed in the coxal endite of the maxilla since $C$. antillensis and C. cubensis had a formula of 24, 7 setae, whereas $C$. vittatus presented a formula of 22, 6 setae. Variations were recorded also in the basal endite of the maxilla, as $C$. antillensis presented a formula of 8, 10 setae, C. vittatus of 8,15 setae and C. cubensis of 10,11 setae. In the margin of the scaphognathite of the maxilla, 60 setae were observed in C. vittatus and C. cubensis, while in $C$. antillensis 53 setae were observed. The three species presented 19 to 21 setae in the exopodites of the uropods; the endopodites presented 8 to 11 setae in $C$. vittatus and 12 to 13 in C. antillensis and C. cubensis. The telson shape is sub oval in the three species and all of them have 8 to 9 setae in the posterior margin.

On the other hand, 22 segments were observed in the antenna of $D$. insignis, while $P$. diogenes presented 16 segments. The $D$. insignis species presented 12 setae on the coxal endite of the maxillule, while in $P$. diogenes 23 setae were observed. In the coxal endite of the maxilla, some variations were also observed, $D$. insignis presented a formula of 24, 7 setae, while $P$. diogenes presented a formula of 23, 7 setae. The basal endite of the maxilla of $D$. insignis presented a formula of 14,15 setae and $P$. diogenes of 9,17 setae. In both species the greatest number of setae was observed in the scaphognathite margin, 71 in D. insignis and 73 in $P$. diogenes. Both species presented also the highest quantity of setae in the exopodites of the uropod of 48-50 in $D$. insignis and 33-34 in $P$. diogenes. The endopodites of the uropods presented from 24 to 28 setae in the two species. The shape of the telson is sub rectangular in both species with 11-12 setae on the posterior margin.

10 segments were observed in the antenna of Calcinus tibicen and Paguristes spinipes, whereas $P$. sericeus showed only 6 segments. The species $C$. tibicen and $P$. spinipes presented 12 setae on the coxal endite of the maxillule, while in $P$. sericeus 5 setae were observed. In the coxal endite of the maxilla variations were also observed as Paguristes species showed a formula of 11,7 setae, being higher in $C$. tibicen which presented a formula of 28,6 setae. The basal endite of the maxilla in $C$. tibicen presented a formula of 6 , 12 setae and the species of Paguristes presented 7, 9 setae. Paguristes species had the lowest quantity of setae in the scaphognathite margin, $P$. spinipes with 26 setae and $P$. sericeus with 23-30 setae; this number increases in $C$. tibicen with 65 setae. The species $P$. sericeus presented from 15 to 17 setae on the exopodites of the uropods, $P$. spinipes from 14 to 20 setae and $C$. tibicen from 20 to 21 setae. The endopodites of the uropods presented from 7 to 8 setae in $P$. sericeus, 11 setae in $P$. spinipes and from 13 to 14 setae in $C$. tibicen. The shape of the telson is sub rectangular, with 9 setae on the posterior margin in $P$. sericeus, 10 setae in $P$. spinipes and 11 setae in $C$. tibicen.
With morphological analysis two identification keys were elaborated, one for the genus level and one for the species of Diogenidae family collected in the southwestern Gulf of Mexico.

\subsection{Identification Key for the Genera of the Megalopae of the Diogenidae Family Present in the Southwestern Gulf of Mexico}

1a. Flagellum of the antenna with more than 16

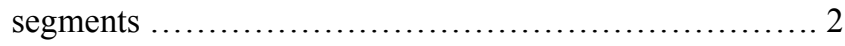

1b. Flagellum of the antenna with less than 14 segments ............................................ 3

2a. Flagellum of the antenna with 16 to 17 segments; 8 to 10 setae in the posterior margin of telson; more than 33 setae in the exopodites of the uropods ............... Petrochirus

2b. Flagellum of the antenna with 18 to 27 segments; more of 12 setae in the posterior margin of telson; four segments in the inner branch of the antennula; more than 48 setae in the exopodites of the uropod ............. Dardanus

3a. Scaphognathite of the maxilla with 23 to 30 setae; 2 segments en the inner branch of the antennules ... Paguristes

3 b. Scaphognathite of the maxilla with 49 to 55 setae; 3 segments en the inner branch of the antennule ............ 4

4a. Scaphognathite of the maxilla with 49 to 60 setae; telson with semioval shape ................... Clibanarius

$4 \mathrm{~b}$. Scaphognathite of the maxilla with 65 setae; telson with sub rectangular shape ..................... Calcinus

\subsection{Identification Key for the Megalopae Species of the Diogenidae Family Present in the Southwestern Gulf of Mexico}

1 a. Telson with sub oval shape, with 8 to 9 setae in the posterior margin (Figs. 2 B y D) .......................... 2

$1 \mathrm{~b}$. Telson with rhomboidal or sub rectangular shape, con 9 a 15 setae in the posterior margin (Figs. 3 B y E; Figs. 4 B, D y F)

2 a. Telson with entire margin, exopodite of uropods with 12-20 plumose setae on the margin; scaphognathite of the maxilla with 60 plumose setae on the margin .............. 3

$2 \mathrm{~b}$. Telson with the posterior margin cleft before the first setae; exopodite of the uropods with 19 to 21 plumose setae on the margin; scaphognathite of the maxilla with 49 to 55 plumose setae in the margin

Clibanarius antillensis (Fig. 2 D-E)

3a. Flagellum of the antenna with 9 segments ... C. tricolor

3 b. Flagellum of the antenna with 10 to 11 segments ... 4

4a. Flagellum of the antenna with 10 segments; basal endite of the maxilla with formula of 10, 11 setae ......................................... C. cubensis

4b. Flagellum of the antenna with 11 segments; basal endite of the maxilla with formula of 8,15 setae ............. C. vittatus (Fig. 2 A-C)

5 a. Rhomboid-shaped carapace; exopodite of uropods

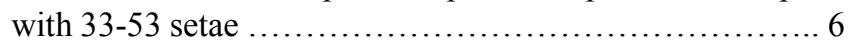

6 a. Exopodite of uropods with 49 to 53 setae; 
scaphognathite of the maxilla with 71 setae on the margin ...................... Dardanus insignis (Fig. 3 A-C)

6 b. Exopodite of uropods with 33 to 39 setae; scaphognathite of the maxilla with 73 setae on the margin ................... Petrochirus diogenes (Fig. 3 D-F)

7 a. With six segments in the flagellum of the antenna; endopodites of uropods with 7 to 8 plumose setae on the margin, exopodite with 15 to 17 setae

Paguristes sericeus (Fig. 4 D y E)

7 b. With 10 segments in the flagellum of the antenna; endopodites of uropods with 9 to 15 plumose setae on the margin

8 a. Scaphognatite of the maxilla with 26 plumose setae on the margin, exopodite of uropods with 14 to 20 plumose setae .

P. spinipes (Fig. 4 A-C)

$8 \mathrm{~b}$. Scaphognatjite of the maxilla with 65 plumose setae on the margin, exopodite of uropods with 20 to 23 plumose setae Calcinus tibicen (Fig. 4 F y G)

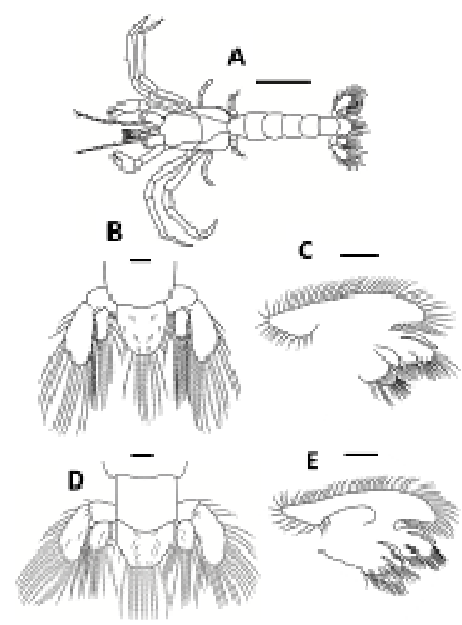

Figure 2. Clibanarius vittatus, A, dorsal view of megalopae; $B$, telson; $C$, scaphognathite. $C$. antillensis, $D$, telson; E, scaphognathite. $1 \mathrm{~mm} . A-C$ modified from Reference [22], D-E modified from Reference [23]. Scales: $A$ $=1.0 \mathrm{~mm} ; B-E=0.1 \mathrm{~mm}$

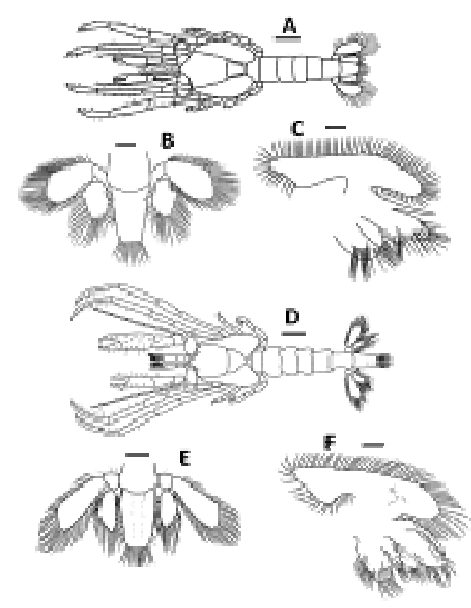

Figure 3. Dardanus insignis, A, dorsal view of megalopae; B, telson; $C$, scaphognathite. Petrichirus diogenes, D, dorsal view of megalopae; $E$, telson; $F$, scaphognathite . A-C modified from Reference [24], D-F modified from Reference [19]. Scales $A, D=1.0 \mathrm{~mm} ; B, E=0.5 \mathrm{~mm} ; C, F=0.1 \mathrm{~mm}$.

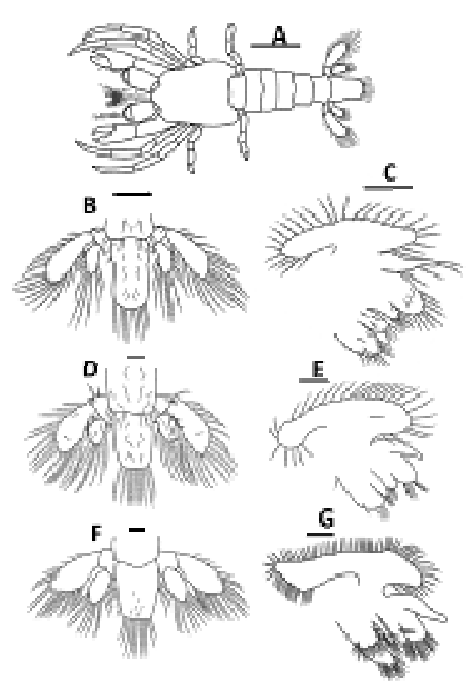

Figure 4. Paguristes spinipes, A, megalopae; B, telson; $C$, scaphognathite. $P$. sericeus, D, telson; E, scaphognathite . Calcinus tibicen, F, telson; $G$, scaphognathite. A-C modified from Reference [20], D-E modified from Reference [21], F-G modified from Reference [18]. Scales: $A=1.0 \mathrm{~mm}$; $B-G=0.1 \mathrm{~mm}$

\section{Discussion}

Analyzing the distribution of the species in the adult stage, it was found that five of them were recorded by Reference [3, $4]$ in the study area, although $D$. insignis and $P$. sericieus are exemplary of the National Collection of Crustaceans, they were classified as inferred presence, so it is through the results obtained in this work with both species of megalopae that their distribution in the area is corroborated.

There is agreement between the features reported by the authors who conducted the original descriptions and what was found in the megalopae collected in the present study.

Particularly, the features that help recognize the megalopa of $C$. vittatus are the oval shape and the nine long setae on the posterior margin of the telson [22], C. cubensis also has these characteristics, but only has 10 segments in the flagellum of the antenna and a different number of setae on the coxal and basal endite of the maxilla. The megalopae of C. antillensis differ mainly in the shape of the telson and the setation pattern of the scaphognathite of the maxilla, $C$. tricolor has nine segments in the flagellum of the antenna [19].

The megalopa of $P$. sericeus is distinguished by the smaller number of setae on the exopodite of the uropods; in other species of the genus as P. oculatus (Fabricius, 1775) differentiation is provided by the presence of three hooks at the endopodite of the uropods, whereas $P$. sericeus has only two hooks [21]. As it is shown in the key, the main difference for the separation with $P$. spinipes is the number of setae on the exopod of the uropods Reference [20] also mentions that other features like the fewer number of setae in the scaphognathite of the maxilla of $P$. spinipes, a greater number of setae over the endopodite of the first maxilliped and exopodite of the third maxilliped with respect to $P$. sericeus. 
Another important feature to differentiate between the genera of the Diogenidae family is the number of segments in the antenna, since the species of the genus Petrochirus have 16 to 17 segments, the species of the genus Dardanus 18 to 27 segments, the species of the genus Calcinus 10 to 13 segments and the species of the genus Paguristes have 4 to 6 segments. The body size of $P$. diogenes and $D$. insignis is the largest in the Diogenidae that have been described. Other features that help distinguish Petrochirus are the size of the chelae and the dactyls' processes of the second and third pereiopods [19].

It is noteworthy that at family level we can recognize some features that help to separate the megalopae from the hermit crabs. Thus, in the Porcellanidae family the carapace is oval notably covered with setae and the endopodites of the uropods are longer than the exopodites. In the species of the Paguridae and Diogenidae families the carapace is rhomboid or rectangular shaped, with few setae and the endopodites of the uropods are shorter than the exopodites. Generally, in the species of the Paguridae family the length of the carapace is less than twice the length of the abdomen and in the species of the Diogenidae family the length of the carapace is two or more times the length of the abdomen.

These keys are the first contribution for the identification of megalopae in the Diogenidae family registered in the coasts of Veracruz State in southwestern Gulf of Mexico.

\section{Acknowledgements}

The funds for the completion of this study were granted by the projects of UNAM PAPIIT IN229011 and FES Iztacala 2009-2010. We appreciate the participation of students from FES Iztacala, the administration of PNSAV, the Secretary of the Navy and Miguel Ángel Lozano-Aburto from the Institute of Ecology and Fisheries (UV) for their support to this project.

\section{References}

[1] S. De Grave, N.D. Pentcheff, S.T. Ahyong, T-Y. Chan, K.A. Crandall, P.C. Dworschak, D.L. Felder, R.M. Feldmann, C.H.J.M. Fransen, L.Y.D. Goulding, R. Lemaitre, M.E.Y. Low, J.W. Martin, P.K.L. Ng, C.E. Schweitzer, S.H. Tan, D. Tshudy, and R. Wetzer, "A classification of living and fossil genera of decapods crustaceans", The Raffles Bulletin of Zoology, vol. 21, pp. 1-109, 2009.

[2] P. A. McLaughlin, T. Komai and R. Lemaitre, "Annotated checklist of anomuran decapod crustaceans of the world (exclusive of the Kiwaoidea and families Chirostylidae and Galatheidae of the Galatheoidea)" Part I Lithodoidea, Lomisoidea and Paguroidea, The Raffles bulletin of Zoology, vol. 23 , pp. 5-107, 2010.

[3] F. Álvarez, J. L. Villalobos and R. Robles, "Listas y comentarios sobre los crustáceos decápodos de Veracruz", Anales del Instituto de Biología, UNAM, vol. 70(1), pp. 1-27, 1999.
[4] F Álvarez, J. L. Villalobos and S. Cházaro-Olvera, "Camarones y cangrejos dulceacuícolas y marinos (Crustacea: Decapoda)", In La biodiversidad en Veracruz. Estudio de estado. Diversidad de especies: conocimiento actual, A. Cruz-Angón, F. G. Lorea-Hernández, V. Hernández-Ortiz and J. E. Morales-Mavil, CONABIO, Gobierno del Estado de Veracruz, Universidad Veracruzana, Instituto de Ecología, A. C. Distrito Federal, México, pp. 287-293, 2011.

[5] A. W. Harvey, "Delayed metamorphosis in Florida hermitcrabs: Multiple cues and constraints (Crustacea: Decapoda: Paguridae and Diogenidae)", Marine Ecology Progress Series, vol. 141, pp. 27-36, 1996.

[6] [6] S. D. Salman, "Larval development of the spider crab Eurynome aspera(Pennant), reared in the laboratory, with a key to the known larvae of the subfamily Pisinae (Brachyura, Majidae)", Crustaceana,vol. 43, pp. 78-88, 1982.

[7] J. W Martin, "Notes and bibliography on the larvae of xanthid crabs, with a key to the known zoeas of the western Atlantic and Gulf of Mexico", Bulletin of Marine Science, vol. 34, pp. 220-239, 1984.

[8] R. W Ingle, "Larval stages of Northeastern Atlantic crabs. An illustrated key", Chapman \& Hall, London, 1992, 384 p.

[9] J. Paula, "A key and bibliography for the identification of zoeal stages of brachyuran crabs (Crustacea, Decapoda, Brachyura) from the Atlantic coast of Europe", Journal of Plankton Research, vol. 18, pp. 17-27, 1996.

[10] D. Pessani, R. Burr and L. Salton, "A key for the identification of the known larval stages of the Mediterranean Brachyura", Invertebrate Reproduction and Development, vol. 33, pp. 191-199, 1998.

[11] D. Boltovskoy (Ed) South Atlantic Zooplankton. Backhuys Publishers, Leiden, The Netherlands, vol. 1-2, 1999, 1706.

[12] G. Hernández, "Morfología larvaria de cangrejos anomuros de la Familia Porcellanidae Haworth, 1825 (Crustácea: Decapoda), con una clave para las zoeas de los géneros del Atlántico occidental”, Ciencia, vol. 7(3), pp. 244-257, 1999.

[13] S. G. Bullard, "Larvae of anomuran and brachyuran crabs of North Carolina: A guide to the described larval stages of anomuran (Families: Porcellanidae, Albuneidae, and Hippidae) and brachyuran crabs of North Carolina, USA", Crustaceana Monographs, Brill Academic Publishers, Leiden, vol. 1,142 p. 2003

[14] J. Medellín-Mora, N. H. Campos, A. Franco-Herrera and J. C. Jaimes, "Taxonomía de larvas zoea de crustáceos decápodos en el área nororiental del mar Caribe colombiano", Boletín de Investigaciones Marinas y Costeras, INVEMAR, vol. 38(2), pp, 55-73, 2009.

[15] S. Cházaro-Olvera, A. Rocha-Ramírez and $H$. Vázquez-López, "Morphological differentiation of megalopae in the family Panopeidae Ortmann, 1893, from a lagoon system inlet in the southwestern Gulf of Mexico", Crustaceana, vol. 79(7), pp. 865-878, 2006.

[16] I. Winfield, S. Cházaro-Olvera, M. Ortiz and U. Palomo-Aguayo, "Lista actualizada de las especies de anfípodos (Peracarida: Gammaridea y Corophiidea) marinos invasores en México", Revista de Biología Marina y Oceanografía, vol. 46(3), pp. 349-361, 2011. 
[17] D. Salas-Monreal,, D. A. Salas de León, M. A. Monreal-Gómez and M. L. Riverón-Enzástiga, "Current rectification in a tropical coral reef system", Coral Reefs, vol. 28, pp. 871-879, 2009.

[18] A. J. Jr. Provenzano, "The larval development of Calcinus tibicen (Herbst) (Crustacea, Anomura) in the laboratory", Biological Bulletin, vol. 123(1), pp. 179-202, 1962.

[19] A. J. Jr. Provenzano, "The complete larval development of the west Indian hermit crab Petrochirus diogenes (L.) (Decapoda, Diogenidae) reared in the laboratory", Bulletin of Marine Science, vol. 18, pp. 143-181, 1968.

[20] A. J. Jr. Provenzano, "Larval development of the hermit crab, Paguristes spinipes Milne-Edwards, 1880 (Decapoda, Diogenidae) reared in the laboratory",Bulletin of Marine Science, vol. 28(3), pp. 512-526, 1978.

[21] A. L. Rice and A. J. Provenzano, "The zoeal stages and the
Glaucothoe of Paguristes sericeus A. Milne-Edwards (Anomura,Diogenidae)", Crustaceana, vol. 8(3), pp. 239-254, 1965.

[22] W. H. Lang and A. M. Young, "The larval development of Clibanarius vittatus (Bosc) (Crustacea: Decapoda: Diogenidae) reared in the laboratory", Biological Bulletin, vol. 152, pp. 84-104, 1977.

[23] F. A. Siddiqui, P. A. McLaughlin and J. A. Crain, "Larval development of Clibanarius antillensis Stimpson, 1859 (Crustacea: Anomura: Diogenidae) reared under laboratory conditions: a comparison between panamanian and brazilian populations", Journal of Natural History, vol. 25(4), pp. 917-932, 1991.

[24] N. J. Hebling and C. B. Mansur, "Desenvolvimento larval de Dardanus insignis (Saussure) (Crustacea, Decapoda, Diogenidaei) em laboratorio", Revista Brasileira de Zoologia, vol. 12(3), pp. 471-491, 1995. 